\title{
INNERVATION OF THE PRONATOR TERES MUSCLE
}

\author{
INERVACIÓN DEL MÚSCULO PRONADOR REDONDO
}

"Nilton Alves; **Paulo Laino Cândido \& ** Renata Frazão

\begin{abstract}
ALVES, N.; CÂNDIDO, P. L. \& FRAZÃO, R. Innervation of the pronator teres muscle. Int. J. Morphol., 22(3):237-240, 2004.
SUMMARY: The pronator quadratus is the principal muscle responsible for pronation of forearm, helped by the pronator teres. To study the innervation of the pronator teres, eighteen forearms from a formol fixed corpses were dissected and the relationship of the median nerve to the pronator teres was examined. The elbow articular line was used as reference point. In all cases the most branches of the median nerve to the pronator teres began in the arm distal third part, whereas the most branches penetrated at the distal half of the forearm proximal third part (75\% in right upper limb and $75.8 \%$ in left upper limb). The treatment of pronator syndrome could be making easier with the knowledge of the anatomical distribution of nerves.
\end{abstract}

KEY WORDS: 1. Anatomy; 2. Pronator teres muscle, 3. Innervation.

\section{INTRODUCTION}

The main responsible for pronation of forearm is the quadratus pronator muscle, which is helped in this movement by the teres pronator muscle. These muscles are supplied by anterior interosseous nerve's and median nerve's branches. The median nerve originates from the medial and lateral fascicle of the brachial plexus. It goes through the arm by the side of the brachial artery (Gray, 1985; Stern, 1997) and in the cubital fossa gives off a branch named anterior interosseous nerve.

Lesions in all brachial plexus are rare, but can occur due to stretching of the plexus; in this case, all arm, forearm, fingers and hand muscles as well as most of shoulder's muscles become paralyzed and suffer from lack of sensibility at entire limb. Partial lesions in brachial plexus can occur, resulting from knife or projectile wounds, or forced traction of arm, especially during birth. Since median nerve supplies most part of muscles related to the pronation of forearm, the flexion of hand and fingers and the thumb opposition, wrist flexion becomes deficient with a ulnar deviation if it is harmed, losing the pronation of forearm, which is replaced by rotation of arm (DiDio, 1974; Stern). There are several points wherein the nerve compression may occur: fibrous arcs formed by the superficial flexor muscle of fingers, teres pronator muscle, or both; the Gantzer muscle and vascular chains surrounding the nerve (Olehnik et al., 1994; Dellon \& Mackinnon, 1987).
Classical compression syndromes of the median nerve are described as pronator syndrome and anterior interosseous nerve syndrome (Dellon \& Mackinnon).

Due to the great importance for clinical doctors, orthopedists and physiotherapists, not only to help in treatment and diagnostic, in recovering of lesions and mainly in case of surgical interventions in points where those nervous branches are located, this study aim to give detailed anatomical informations about the teres pronator muscle innervation.

\section{MATERIAL AND METHOD}

Eighteen forearms were dissected in formol fixed corpses belonging to the Escola Paulista de Medicina, Universidade Federal de São Paulo e Universidade Cruzeiro do Sul. The causa mortis had not altered the structures of the forearms. There were one female and ten male corpses.

The forearms were measured with a regular ruler. In this procedure the elbow articular line (determined by the medial and lateral epicondyles of humerus), and the wirst articular line (determined by the styloid processes of radius and ulna) were taken as reference.

\footnotetext{
" Universidade Estadual Paulista Júlio de Mesquita Filho, Araraquara, Brasil

*** Universidade de Santo Amaro, São Paulo, Brasil.
} 
After identification of the median nerve, through the course of the arm, the teres pronator muscle was detached from the lateral and medial face of radius, where it was inserted, for better view of nervous branches as extend to this muscle (Fig. 1). Only eight forearms were used to measure the nervous branches destined to the teres pronator muscle.

The nervous branches were measured in reference to the elbow articular line, using the Mitutoyo digital pachimeter.

As topographic reference to the levels of origin and penetration of the nervous branches, the forearm was divided in thirds: proximal, medium and distal; each third we considered a proximal and a distal half.

According to the obtained data, the means of the forearms length, the anterior interosseous nerve origins, the number of nervous branches and the penetration points of the nervous branches could be calculated. The most proximal and distal penetrations in relation to elbow articular line were also observed.

\section{RESULTS}

Right superior member. The forearm length varied from 23.7 to $27.5 \mathrm{~cm}$, with average length of $25.3 \mathrm{~cm}$ (Table I).

Median nerve. The mean length of the branches of the median nerve was $5.9 \mathrm{~cm}$, varying from 2.3 to $9.5 \mathrm{~cm}$.

The origin number of the median nerve branches to teres pronator muscle varied from 1 to 3 , with average of 1.8 origins.

The most proximal origin was located $4.0 \mathrm{~cm}$ above the elbow articular line, and the most distal origin was $1.0 \mathrm{~cm}$ below the line.

$93.3 \%$ of the nervous branches originated at the distal third of the arm and $6.7 \%$ of the branches originated in the proximal half of the forearm proximal third.

The penetrating branches number of the median nerves into the muscle varied from 3 to 10 , with average of 6.5 penetrating branches.

The most proximal penetration was at the elbow articular line in one of the forearms, and the most distal penetration was $7.2 \mathrm{~cm}$ below the referred line, and the penetration mean point of the branches was $6.5 \mathrm{~cm}$ distal to the elbow articular line.
As for the location of the penetrations, $15.4 \%$ of the branches penetrated at the proximal half of the forearm proximal third, $75 \%$ of the branches penetrated at the distal half of the forearm proximal third and $9.6 \%$ of the branches penetrated at the proximal half of the forearm mid-third.

Left superior member. The forearm length varied from 22.5 to $27 \mathrm{~cm}$, with average length of $25.1 \mathrm{~cm}$.

Median nerve. The mean length of the branches of the median nerve was $6.5 \mathrm{~cm}$, varying from 2.2 to $9.3 \mathrm{~cm}$.

The origin number of the median nerve branches to teres pronator muscle varied from 1 to 3 origins, with average of 1.3 origins.

The most proximal origin located $4.9 \mathrm{~cm}$ above the elbow articular line, and the most distal origin was $1.6 \mathrm{~cm}$ below the line.

$91.6 \%$ of the nervous branches originated at the distal third of the arm and $8.4 \%$ of the branches originated in the proximal half of the forearm proximal third.

The penetrating branches number of the median nerve to the muscle varied from 3 to 10 , with average of 7.3 penetrating branches.

The most proximal penetration was $0.5 \mathrm{~cm}$ below the elbow articular line in one of the forearms, the most distal penetration was $7.5 \mathrm{~cm}$ below the referred line, and the penetration mean point of the branches was $6.5 \mathrm{~cm}$ distal to the elbow articular line.

As for the location of the penetrations, $12.1 \%$ of the branches penetrated at the proximal half of the forearm proximal third, $75.8 \%$ of the branches penetrated at the distal third of the proximal third forearm and $12.1 \%$ of the branches penetrated at the proximal half of the forearm mid-third.

\section{DISCUSSION}

As an anatomical variation, we could notice that in only one case a median nerve branch destined to the teres pronator muscle divided itself to innervate the superficial flexor muscle of the fingers; this fact has not been found in literature. Sunderland (1968) claimed that the medial cutaneous nerve of arm could eventually innervate the teres pronator muscle, fact which was observed in only one case studied. 
Table I. Data about the innervation of the teres pronator muscle.

\section{Forearms length average}

Most proximal origin

Most distal origin

Average of the origin points of the nervous branches

Average of the number of origins

Branch of median nerve with most proximal penetration

Branch of median nerve with most distal penetration

Average of the points of penetration of the nervous branches

Average of the number of penetrations

Average of the length of the median nerve branches

e.a.l. = elbow articular line

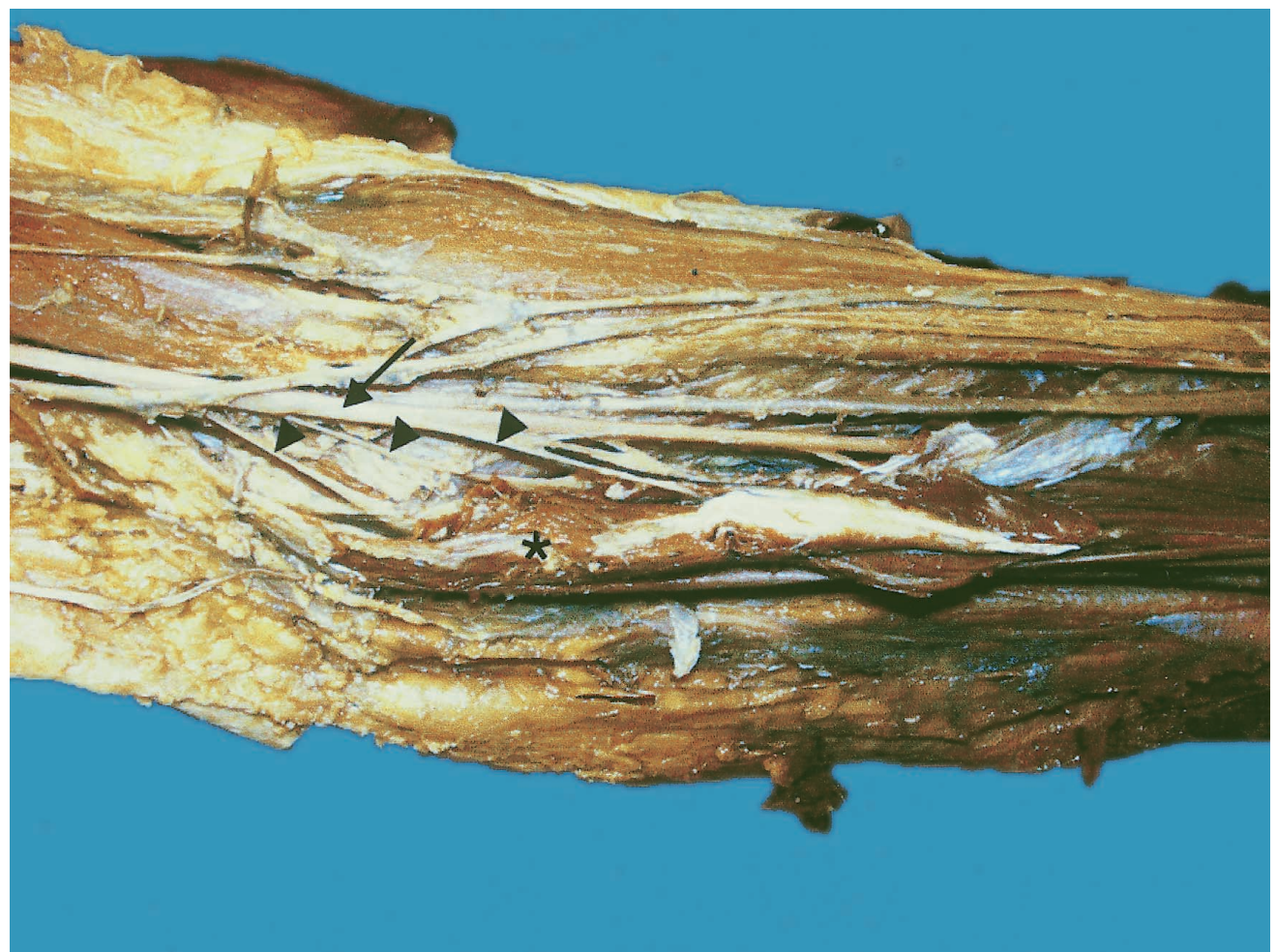

Fig. 1. Median nerve (arrow) and some of its branches (arrowhead) extend to the pronator teres muscle (*).
Superior Left Member

$21.5 \mathrm{~cm}$

$4.9 \mathrm{~cm}(\uparrow$ e.a.1.)

$1.6 \mathrm{~cm}(\downarrow$ e.a.l. $)$

$4.9 \mathrm{~cm}(\downarrow$ e.a.1.)

1.3

$0.5 \mathrm{~cm}(\downarrow$ e.a.1. $)$

$7.5 \mathrm{~cm}(\downarrow$ e.a.1. $)$

$6.5 \mathrm{~cm}$

7.3

$6.4 \mathrm{~cm}$

Comparing to these studies, we could notice that in most cases the median nerve was located between the humeral and ulnar heads of that muscle. Only Shäfer et al. y Ferner related cases where the median nerve was located in an anterior position in relation to the teres pronator muscle, fact which was not noticed in our study.

Several authors show the possible compression points of this nerve, which would lead to some syndromes very well known.

Some authors (Gray; Beaton \& Anson, 1939; Shäfer et al., 1909; Ferner, 1937) studied the relation between the teres pronator muscle and the median nerve. Gray, found in $16 \%$ of the studied corpses the median nerve in a deep situation in relation to the humeral head of this muscle in the absence of an ulnar head, or even going through the belly of this head. Beaton \& Anson, observed that in $82 \%$ of the cases, the median nerve was located between the deep and superficial head of the teres pronator muscle during the dissection of 240 superior members; in $9 \%$ of the cases the ulnar head of the teres pronator muscle was absent; in $7 \%$ of the cases the median nerve was deeply located in relation to the ulnar head of the teres pronator muscle and in $2 \%$ of the cases the nerve went through the belly of the humeral head of the teres pronator muscle.
This compression could be associated to several causes, e.g., a sequela resulting from vein cauterization (Lake, 1974); fibrous arcs formed by the superficial flexor muscle of the fingers, teres pronator, or both; compression caused by the Gantzer muscle, accessory head of the long flexor muscle of thumb (Collins \& Weber, 1983; Dellon \& Mackinnon; Olenick et al., Shirali et al., 1998); anatomical variations and vascular chains surrounding the nerve, as related by Braun \& Spinner, 1991, they noticed during a surgical intervention, that the compression of the nerve occurred in the distal part of the arm, caused by communicating veins that jointed to the cephalic and basilic veins and with the brachial vein through a bicipital aponeurosis. 
ALVES, N.; CÂNDIDO, P. L. \& FRAZÃO, R. Inervación del músculo pronador redondo. Int. J. Morphol., 22(3):237-240, 2004.

RESUMEN: El músculo pronador redondo actúa como motor secundario en la pronación del antebrazo, siendo el músculo pronador cuadrado motor primario de esta acción. Estudiamos la inervación del músculo pronador redondo en 8 antebrazos de cuerpos fijados en formol. Fueron disecados y examinados el nervio mediano y su inervación para el músculo pronador redondo. La línea articular del codo fue usada como punto de referencia. En todos los casos, la mayoría de los ramos del nervio mediano para el músculo pronador redondo se originaban en el tercio distal del brazo, mientras que, la mayor parte de los ramos penetraba en la mitad del antebrazo, proximal al tercio distal (75\% en el miembro superior derecho y $75.8 \%$ en el miembro superior izquierdo). El tratamiento del síndrome pronador podría ser más fácil conociendo mejor la distribución anatómica de los nervios.

PALABRAS CLAVE: 1. Anatomía; 2. Músculo pronador redondo; 3. Inervación.

\section{REFERENCES}

Beaton, L. E. \& Anson, B. J. The relation of the median nerve to the pronator teres muscle. Anat. Rec., 75:23-6, 1939.

Braun, R. M. \& Spinner, R. J. Spontaneous bilateral median nerve compressions in the distal arm. J. Hand Surg., $16 a(2): 244-7,1991$.

Collins, D. N. \& Weber, E. R. Anterior interosseous nerve syndrome. South. Med. J., 76(12):1533-7, 1983.

Dellon, A. L. \& Mackinnon, S. E. Musculoaponeurotic variations along the course of the median nerve in the proximal forearm. J. Hand Surg., 12b(3):359-63, 1987.

DiDio, L. J. A. Sinopse de anatomia. Rio de Janeiro, Guanabara Koogan, 1974. pp 478-81.

Ferner, H. Ein abnormer verlauf des nervus medianus vor dem m. pronator teres. Anat. Anz., 84:151-6, 1937.

Gray, H. Anatomy of the human body. Philadelphia, Lea \& Febiger, 1985. pp.1213-9.

Lake, P. A. Anterior interosseous nerve syndrome. $J$. Neurosurg., 41(3):306-9, 1974.

Olehnik, W. K.; Manske, P. R. \& Szerzinski, J. Median nerve compression in the proximal forearm. J. Hand Surg., 19(1):121-6, 1994.

Shäfer, E. A.; Symington, J. \& Bryce, T. H. Quain's anatomy. Green, London, 1909. pp 158-6, 230-8.

Shirali, S.; Hanson, M.; Branovacki, G. \& Gonzalez, M. The flexor pollicis longus and its relation to the anterior and posterior interosseous nerves. J. Hand Surg., 23(2):170-2, 1998.
Stern, J. T. Jr. Core concepts in anatomy. Philadelphia, Lippincott, 1997. pp 158-60, 230-8.

Sunderland, S. Nerves and nerve injuries. Baltimore: Williams \& Wilkins, 1968. pp 736-7, 742, 747-52.

Correspondence to: Prof. Dr. Nilton Alves Universidade Estadual Paulista gúlio de Mesquita Filho

Rua Humaitá, 1680

CEP 148011-903

Campus Araraquara - Araraquara/SP

Brasil

Email:niltonnalves@hotmail.com

Received: 30-06-2004

Accepted: 09-08-2004 